\title{
本邦に打ける小児の在宅酸素療法の現状
}

\author{
加野 草平，西間 三馨 \\ (国立療養所南福岡病院小児呼吸器科)
}

\begin{abstract}
要旨：全国の大学病院ならびに日本小児呼吸器疾患学会参加施設（計265施設）に対し小児の在宅 酸素療法（HOT）に関するアンケート調査を行なった。HOT 対象児は106例（男63例，女43例） で，平均年齢は 5.2 歳， $67.9 \%$ が 5 歳以下の症例であった。対象疾患では，呼吸器疾患が61例 ( 57.5 \%) と最も多く，心血管系疾患 35 例 $(33.0 \%)$, 多発奇形および神経筋疾患12例 $(11.3 \%)$ であっ た。HOT 開始時の動脈血液ガス所見では，大気吸入下で $\mathrm{PaO}_{2} 48.5 \pm 15.0 \mathrm{mmHg}, \mathrm{Paco}_{2} 46.3 \pm$ $12.5 \mathrm{mmHg}(\mathrm{n}=59)$ であった。酸素供給源の種類は, 吸着型酸素濃縮器が68例（64.2\%）と最も 多く，膜型28例 (26.4\%)，酸素ボンべ13例（12.3\%）であった。HOT 施行例の転帰については, 死亡18例 (17.0\%)で, 病状の改善による HOT 中止例が30例(28.3\%) 存在していた。小児の HOT の特徵として，低年齢児，小览特有の疾患を対象とすることが多く，また将来 HOT を中止できる 症例がかなり存在すること等があげられる。
\end{abstract}

\section{The present state of home oxygen therapy in children}

We investigated the present state of home oxygen therapy (H.O.T.) in children by questionnaires to the pediatric department of universities and hospitals participated in Japanese Society of Pediatric Pulmonology. Total number of cases were 106, consisting of 63 males and 43 females. The average age of the cases receiving H.O.T. was 5.2 years of age, 67. $9 \%$ of these cases was under 5 years of age. Diagnosis and the number of cases were following; respiratory diseases 61 cases $(57.5 \%)$, cardiovascular diseases 35 cases $(33.0 \%)$, multiple anomaly and neuro-muscular diseases 12 cases (11.3\%). The value of arterial blood gases under room air were following when H.O.T. was begun; $\mathrm{PaO}_{2} 48.5 \pm 15.0 \mathrm{mmHg}, \mathrm{Paco}_{2}$ $46.3 \pm 12.5 \mathrm{mmHg}(\mathrm{n}=59)$, Oxygen delivary system was consisted of oxygen concentrator $(96$ cases, $90.8 \%$ ) and oxygen cylinder (13 cases, 12.3\%). Concerning for prognosis, 18 of 106 cases died, 30 cases weaned from home oxygen.

Based on these result, characteristics of H.O.T. in children were that the most of underlying diseases was characteristic of child, many cases were younger children and weaned from home oxygen.

\section{はじめに}

1950年代より，欧米において在宅酸素療法 (Home Oxygen Therapy, 以下 HOT と略す) が試みられ始め，米国においてその施行例は現 在約 50 万人と推定されている。我が国における その実数は，1985年 3 月から保険適応になって
以来, 増加しており, 現在約 1 万人以上が HOT を受けている。しかし，小児のHOTについて は, その実数, 対象疾患, 適応等についての検 討がなされていないのが現状である。そこで小 児の HOT に関するアンケート調査を行ない, その現状, 問題点について検討した。 


\section{シンポジウム II}

\section{対象ならびに方法}

対象は小児科において HOT を受けている症 例で，1984年以降の症例とした。アンケート対 象施設は, 全国の大学病院と日本小児呼吸器疾 患学会参加施設の計265施設で, 210施設からの 回答がありその回収率は $79.2 \%$ あった。本ア ンケート調査により対象疾患, 年齢分布, HOT に至るまでの期間, HOT 開始時の動脈血液ガ ス所見, 酸素供給源の種類とその流量, 投与方 法, 吸入時期, 転帰などについての検討を行な つた。なお，本調査は1989年 4 月に行なった。

\section{結果}

\section{1 症例数と対象疾患}

今回のアンケートでの HOT 施行例の総数は 106例で, 男児63例，女児43例(男:女 $=3: 2$ ) であった。小児におけるHOTの対象疾患を Table 1 に示す。呼吸器疾患, 心血管系疾患, 多発奇形ならびに神経筋疾患に大きく分けら れ, 呼吸器疾患が 61 例 $(57.5 \%)$ と最も多く, その内の半数以上が, Bronchopulmonary dysplasia (BPD) と Wilson-Mikity 症候群で占 められていた。心血管系の疾患は35例 $(33.0 \%)$ で, その内, 先天性心疾患が26例と大部分を占 め, ついで原発性肺高血圧症が 8 例であった。 多発奇形ならびに神経筋疾患は 12 例（11.3\%） であった。

\section{2 年歯分布}

HOT 施行例の年齢分布を Figure 1 に示す。 平均年齢は5.2歳で, 1 歳台にピークを認め, 全

Table 1 Diagnosis and number of cases receiving

\begin{tabular}{|c|c|}
\hline diagnosis & No. of cases ( $(\boldsymbol{z})$ \\
\hline $\begin{array}{l}\text { 1. respiratory disease } \\
\text { bronchopulmonary dysplasia(BPD) } \\
\text { Wilson-Mikity syndrome } \\
\text { interstitial pneumonia or pulmonary fibrosis } \\
\text { bronchiectasis } \\
\text { emphysema } \\
\text { diffuse panbronchiol itis(DPB) } \\
\text { others } \\
\text { 2. cardiovascular disease } \\
\text { congenital heart disease } \\
\text { primary pulmonary hypertention(PPH) } \\
\text { hypertensive heart failure } \\
\text { 3. multiple anomaly and neuro-muscular disease. }\end{array}$ & $\begin{array}{l}61(57.5 z) \\
28(26.4 z) \\
10(9.4 z) \\
8(7.5 z) \\
3(2.8 z) \\
2(1.9 z) \\
2(1.9 z) \\
8(7.5 z) \\
35(33.07) \\
26(24.5 z) \\
8(7.5 z) \\
1(0.9 z) \\
12(11.3 z)\end{array}$ \\
\hline total & $106(100 z)$ \\
\hline
\end{tabular}

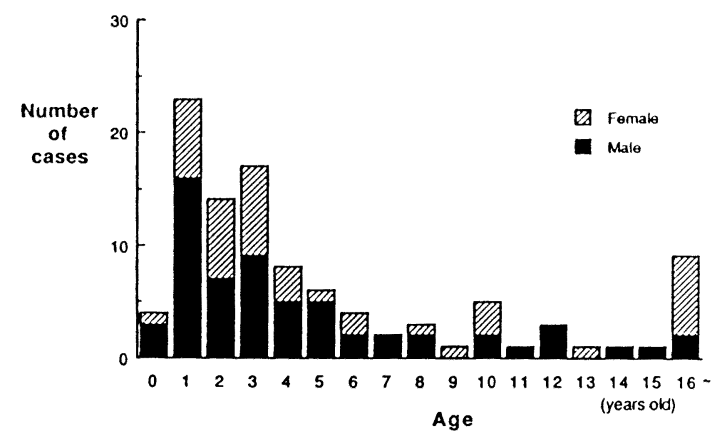

Fig. 1 Age distribution of children receiving H.O.T.

体の $67.9 \%$ が 5 歳以下の乳幼児であった。

3 HOT 開始時の動脈血液ガス所見

HOT 開始時の動脈血液ガス所見では, 大気 吸入下で, $\mathrm{PaO}_{2} 48.5 \pm 15.0 \mathrm{mmHg}, \mathrm{Paco}_{2}$ $46.3 \pm 12.5 \mathrm{mmHg}(\mathrm{n}=59)$ と hypoxemia が著 明で, 酸素吸入下では, $\mathrm{PaO}_{2} 74.8 \pm 34.3$ $\mathrm{mmHg}, \mathrm{PaCO}_{2} 44.8 \pm 10.5 \mathrm{mmHg}(\mathrm{n}=58)$ で あった。

近年, 非侵襲的に患児の酸素化の指標として pulse oxymeter が用いられているが, 動脈血液 ガスの代りに pulse $\mathrm{So}_{2}$ で代用している施設も あり，その值は大気吸入下で $79.4 \pm 12.2 \%(\mathrm{n}=$ 16), 酸素吸入下で $90.8 \pm 12.1 \%(n=17)$ であっ た。

\section{4 酸素供給源と酸素投与時期}

HOT 施行例の酸素供給源は, 酸素濃縮器が 96例 $(90.6 \%)$ と最も多く，その内，吸着型酸 素濃縮器が 68 例と約 $2 / 3$ 占め, 残りの $1 / 3$ が膜 型の酸素濃縮器であった。酸素ボンべ使用例は 13例と全体の約 $10 \%$ で，このうち 4 例が酸素濃 縮器との併用例であった。

酸素吸入の 1 日における時期に関しては，1 日中行っているものが55例 $(51.5 \%)$ で，夜間 のみのものは43例 $(40.6 \%)$ であった。また心 疾患でファロー四徵症のように, 低酸素発作に 対してのみ使用しているものが 4 例であった。

5 流量ならびに投与方法

酸素投与法別の症例数, 年齢, 酸素流量を 


\section{シンポジウし II}

Table 2 に示す。酸素の投与方法では,鼻力ニュ 一ラ使用例が50例 $(47.2 \%$ ） と最も多く，次い で酸素テント使用例が22例, 鼻カテーテル使用 例13例, フェイスマスク使用例が10例であった。 気管切開を施行されそこから酸素投与を受けて いるものは 8 例で, ヘッドボックス使用例は 2 例にすぎなかった。それぞれの酸素投与方法に おける年齢に関しては, 酸素テント, 鼻カテー テルにおいて平均年齢がやや低いが各投与間に おいて有意な差はなかった。酸素の流量に関し ては, 鼻カニューラ, 鼻カテーテル, 気管切開 例においては流量が少なく, 酸素テント, フェ イスマスク使用例において高流量を必要として いた。

\section{6 再入院の頻度}

1 年以上 HOT を受けていた症例の急性増悪 による 1 年間の入院回数は, 全く入院を要さな かった症例が15例 (44.1\%) で，19例 (55.9\%) が急性増悪による入院を要していた。入院回数 では，3回以下がほとんどで，一年の内，4回 以上入院を必要としているものは 2 例にすぎな かった。

7 予後

今回の調査では病状の改善による HOT 中止
例が106例中30例あり，全体の $28.3 \%$ であた。 疾患別では, BPD, Wilson-Mikity 症候群, 先 天性心疾患がほとんどで, この 3 疾患で 25 例と 全体の $83.3 \%$ 占めていた。これら中止例の平 均 HOT 期間は, BPD が9.0 カ月, Wilson-Mikity 症候群 9.5 力月, 先天性心疾患 6.5 力月で, ほとんどの症例は 2 年以内に HOT を中止して いた（Table 3 )。

死亡例に関しては，18例 (17.0\%) がHOT 中 に死亡していた (Table 4)。死亡例の主な疾患 は, 先天性心臓病が 6 例と最も多く, 次いで肺 線維症，18 trisomy がそれぞれ 2 例ずつで, BPD, Wilson-Mikity 症候群での死亡はそれぞ れ 1 例ずつであった。またHOTを開始して死 亡に至るまでの期間に関しては, 開始後半年以 内に死亡したものが18例中11例 (61.1\%) で， 心疾患の 6 例全例が開始後 3 力月以内に死亡し ていた。死亡例における死亡場所は，18例中 3 例 $(16.6 \%)$ が自宅で，残りの15例中14例は病 院内で死亡しており，急性増悪により入院しそ のまま死亡したものと考えられる。

\section{考案}

1976年，PinneyらがBPDの乳児に対して

Table 2 No. of cases, average age and oxygen flow in different methods of oxygen supply

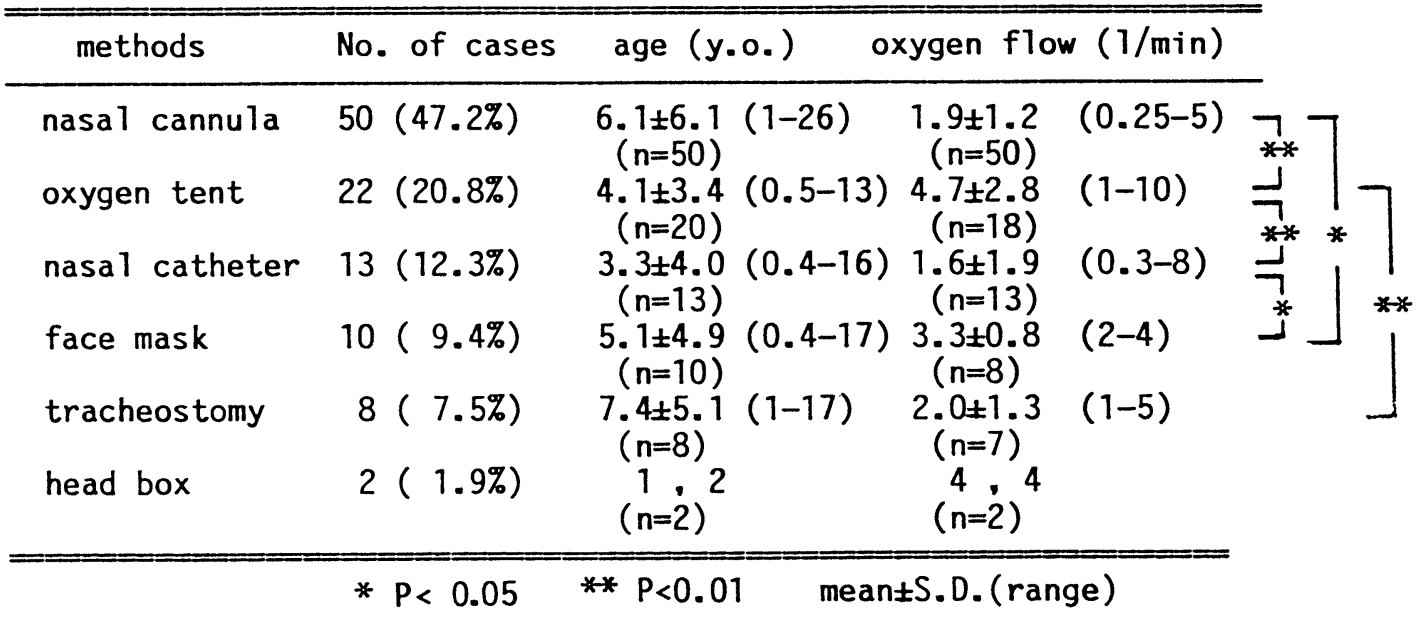




\section{シンポジウム II}

Table 3 Diagnosis in the cases weaned from home oxygen and duration of H.O.T.

\begin{tabular}{|c|c|c|c|}
\hline diagnosis & & No. of cases & duration (months) \\
\hline $\begin{array}{l}\text { BPD } \\
\text { W-M syndrome } \\
\text { CHD* } \\
\text { PPH } \\
\text { pulmonary hypoplasia } \\
21 \text { trisomy } \\
\text { first and second branchial } \\
\text { syndrome } \\
\text { hypertensive heart failure }\end{array}$ & $\begin{array}{l}(n=28) \\
(n=10) \\
(n=26) \\
(n=8) \\
(n=1) \\
(n=1) \\
(n=1) \\
(n=1)\end{array}$ & $\begin{array}{r}11 \text { cases } \\
8 \text { cases } \\
6 \text { cases } \\
1 \text { case } \\
1 \text { case } \\
1 \text { case } \\
1 \text { case } \\
1 \text { case }\end{array}$ & $\begin{array}{c}9.0 \pm 5.8(2-19) \\
9.5 \pm 7.6(4-27) \\
6.5 \pm 5.6(1-15) \\
21 \\
? \\
6 \\
3 \\
13\end{array}$ \\
\hline total & & $30 / 106$ & \\
\hline
\end{tabular}

* 2 cases of PA atresia. TOF were operated.

\begin{tabular}{|c|c|c|}
\hline diagnosis & No. of cases & duration(months) \\
\hline congenital heart disease & 6 cases & \\
\hline VSD, E i semmenger syndrome & 1 case & 1 \\
\hline ECD, PH, Down syndrome & i case & 2 \\
\hline & 1 case & 3 \\
\hline Trunchus arteriosus & 1 case & 2 \\
\hline single atrium, ventricle & $i$ case & 2 \\
\hline TOF & 1 case & $i$ \\
\hline pulmonary fibrosis & 2 cases & 14,31 \\
\hline 18 trisomy & 2 cases & 1,11 \\
\hline Primary pulmonary hypertention (PPH) & 1) 1 case & 49 \\
\hline bronchopulmonary dysplasia (BPD) & 1 case & 4 \\
\hline Wilson-Mikity syndrome & 1 case & $i$ \\
\hline $\begin{array}{l}\text { congenital cystic adenomatoid } \\
\text { malformation of the lung (CCAM) }\end{array}$ & 1 case & 2 \\
\hline diffuse panbronchiolitis (DPB) & 1 case & 69 \\
\hline emphysema & $1 \mathrm{c}$ & 44 \\
\hline I cell diseas & i case & 11 \\
\hline ataxia teleangiectasia & 1 case & 3 \\
\hline ( & $\begin{array}{l}8 / 106 \text { cases } \\
(17.0 \%)\end{array}$ & $\begin{array}{c}13.9 \pm 19.8 \\
\text { (meantS.D.) }\end{array}$ \\
\hline
\end{tabular}

HOT を施行して以来, BPD, Wilson-Mikity 症候群等の乳児の慢性呼吸障害や先天性心疾患 の症例に対する HOTの有用性が報告されてき

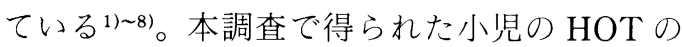
特徵ならびに問題点として，まず第 1 に小巟の HOT の対象疾患が多岐にわたっている点があ げられる。特に BPD, Wilson-Mikity 症候群, 先天性心疾患など小児特有の疾患が今回の調査 対象にかなり含まれており，今後その適応を考 えていく上で重要と考えられた。第 2 に小児の
HOT 施行例の中に, 病状の改善により在宅酸 素を中止できる症例がかなり存在することがあ げられる。特に, BPD, Wilson-Mikity 症候群 に関しては, HOT 施行中の死亡例は少なく, か つ, 中止できている症例が多い事は, 今後 HOT を進めていくうえで, 明るい材料と考えられる。 また, 先天性心疾患に関しては, 今回の調査に おいて26例中 6 例が手術などにより HOTを中 止できている半面, 死亡例も 6 例あり, 適応を 考える上で注意が必要である。第 3 に小児では 低年齢児を対象とすることが多いため，酸素の 投与方法についても個々の症例の年齢, 病状に あわせてその投与方法を工夫しなければならな い。第 4 に成人と比べ動脈血酸素分圧 $\left(\mathrm{PaO}_{2}\right)$ の值にかなりのばらつきとが存在し, しかも $\mathrm{PaO}_{2}$ がかなり低い症例がいたことである。対象 児に低年齢児が多かったことから実際にこの值 が安定期のものとは必ずしもいえないが, 動脈 血液ガス所見だけでなく非侵襲的な pulse oxymeterでの適応も含め, 今後検討していく 必要があると考えられた。最後に, 両親の協力 を如何に得るかという問題があげられる。特に 小児の HOT の場合, 両親の在宅酸素療法に対 する精神的, 肉体的, 経済的負担はかなり強い 


\section{シンポジウム II}

と考えら机, 両親への教育, 指導, 援助をいか に行なっていくか, さらに，実際今回の調査に おいて自宅死亡が 3 例あることからも在宅モ二 ターの必要性を検討すると共に, 現在の保険制 度の見直しが，今後 HOT を普及していく上で 重要であると考えられた。

最後に, 今回の調查に御協力頂きました各施 設の諸先生方, ならびに貴重な症例を提供して いただきました各施設（旭川医科大学小児科， 㷌山雅人先生, 旭中央病院小児科, 喜田善和先 生, 足利赤十字病院小児科, 丹羽伊知郎先生, 大阪大学医学部小児科, 佐野哲也先生, 大阪府 立羽曳野病院小児科, 林田道昭先生, 大阪市立 北市民病院, 武知哲久先生, 関西医科大学小児 科, 小島崇嗣先生, 北里大学医学部小巟科, 中 嶋英彦先生, 九州大学医学部小児科, 久木田穣 次先生, 九州厚生年金病院小児科, 高橋保彦先 生, 京都府立医科大学小児科, 越智雅晴先生, 久留米大学医学部小児科, 赤木禎治先生, 群馬 県立小児医療センター, 曽根克彦先生, 慶応義 塾大学医学部小児科, 小佐野 満先生, 国立小 児病院麻酔科, 阪井裕一先生, 国立小倉病院小 児科, 守田英子先生, 埼玉医科大学小児科, 中 里明彦先生，鈴木 博先生，産業医科大学小照 科, 白川嘉継先生, 静岡赤十字病院小児科, 池 田稲穂先生, 自治医科大学小児科, 下泉秀夫先 生, 順天堂大学医学部附属浦安病院小児科, 井 上成彰先生, 昭和大学医学部小览科, 梅田 陽 先生, 帝京大学医学部附属溝口病院小览科, 有 村 章先生, 東京女子医科大学附属第二病院小 児科, 多田羅勝義先生, 東邦大学医学部第一小 児科, 山本 真先生, 都立清瀬病院小児科, 黒
川博先生, 名古屋市立大学医学部小児科, 松 本 博先生, 日赤医療センタ一小児科, 片岡 正 先生, 福岡大学医学部小览科, 雪竹 浩先生, 北海道大学医学部小巟科, 信太 知先生, 北海 道立小児総合保健センター, 梅津征夫先生, 松 户市立病院小児科, 長谷川久弥先生, 三菱水島 病院小児科, 小谷信行先生, 山口大学医学部小 児科，塚原正人先生）の先生方に深謝いたしま す。

\section{文献}

1) Pinney, M.A., Cotton, E.K.: Home management of bronchopulmonary dysplasia. Pediatrics 58:856-859, 1976.

2 ) Donn, S. : Cost effectiveness of home management of bronchopulmonary dysplasia. Pediatrics 70:330-331, 1982.

3 ) Campbell, A.N., Zarfin, Y., Groenveld, M., et al: Low flow oxygen therapy in infants. Arch. Dis. Child. $58: 795-798,1983$.

4) Abman, S.H., Accurso, F.J., Koops, B.L. : Experience with home oxygen in the management of infants with bronchopulmonary dysplasia. Clin. Pediatr. 23 : 471-476, 1984.

5 ) Thilo, E.H., Comito, J., McCulliss, D. : Home oxygen therapy in the newborn. Am.J. Dis. Child. 141: 766-768, 1987.

6 ) Sauve, R.S., McMillan, D.D., Mitchell, I., et al: Home Oxygen Therapy out come of infants discharged from NICU on continuous treatment. Clin. Pediatr. 28: 113-118, 1989.

7 ) Hudak, B.B., Allen, M.C., Hudak, M.L., et al : Home oxygen therapy for chronic lung disease in extremely low-birth-weight infants, Am. J. Dis. Child. 143: 357-360, 1989.

8 ) Bowyer, J.J., Busst, C.M., Denison, D.M., et al : Effect of long term oxygen treatment at home in children with pulmanary vascular disease Br. Heart J. 55 : 385 390, 1986. 